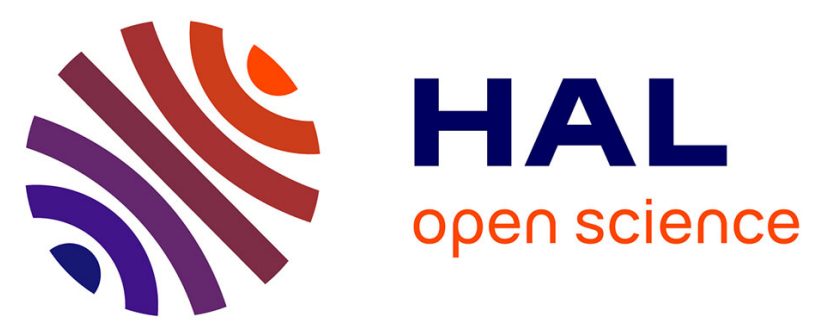

\title{
Conformational and thermal characterization of a synthetic peptidic fragment inspired from human tropoelastin: Signature of the amyloid fibers
}

Jany Dandurand, Valérie Samouillan, Marie-Hélène Lacoste-Ferré, Colette Lacabanne, Brigida Bochicchio, Antonietta Pepe

\section{To cite this version:}

Jany Dandurand, Valérie Samouillan, Marie-Hélène Lacoste-Ferré, Colette Lacabanne, Brigida Bochicchio, et al.. Conformational and thermal characterization of a synthetic peptidic fragment inspired from human tropoelastin: Signature of the amyloid fibers. Pathologie Biologie, 2014, vol. 62, pp. 100-107. 10.1016/j.patbio.2014.02.001 . hal-00980025

\section{HAL Id: hal-00980025 https://hal.science/hal-00980025}

Submitted on 17 Apr 2014

HAL is a multi-disciplinary open access archive for the deposit and dissemination of scientific research documents, whether they are published or not. The documents may come from teaching and research institutions in France or abroad, or from public or private research centers.
L'archive ouverte pluridisciplinaire HAL, est destinée au dépôt et à la diffusion de documents scientifiques de niveau recherche, publiés ou non, émanant des établissements d'enseignement et de recherche français ou étrangers, des laboratoires publics ou privés. 


\section{OATAO \\ Open Archive Toulouse Archive Ouverte}

\section{Open Archive TOULOUSE Archive Ouverte (OATAO)}

OATAO is an open access repository that collects the work of Toulouse researchers and makes it freely available over the web where possible.

This is an author-deposited version published in : http://oatao.univ-toulouse.fr/ Eprints ID : 11369

To link to this article : DOI:10.1016/j.patbio.2014.02.001

URL : http://dx.doi.org/10.1016/j.patbio.2014.02.001

\section{To cite this version :}

Dandurand, Jany and Samouillan, Valérie and Lacoste-Ferré, MarieHélène and Lacabanne, Colette and Bochicchio, Brigida and Pepe, Antonietta Conformational and thermal characterization of a synthetic peptidic fragment inspired from human tropoelastin: Signature of the amyloid fibers. (2014) Pathologie Biologie, vol. 62 $\left(\mathrm{n}^{\circ}\right.$ 2). pp. 100-107. ISSN 0369-8114

Any correspondance concerning this service should be sent to the repository administrator: staff-oatao@listes-diff.inp-toulouse.fr 


\title{
Conformational and thermal characterization of a synthetic peptidic fragment inspired from human tropoelastin: Signature of the amyloid fibers
}

\section{Caractérisation conformationnelle et thermique d'un fragment peptidique synthétique inspiré de la tropolélastine humaine : signature des fibres amyloïdes}

\author{
J. Dandurand ${ }^{\text {a }}$, V. Samouillan ${ }^{\text {a,* }}$, M.H. Lacoste-Ferre ${ }^{a}$, C. Lacabanne ${ }^{\text {a }}$, \\ B.Bochicchio ${ }^{\text {b }}$, A. Pepe ${ }^{\text {b }}$ \\ a Physique des Polymères, CIRIMAT UMR 5085, Institut Carnot, Université Paul Sabatier, 118, route de Narbonne, 31062 Toulouse cedex, France \\ ${ }^{\mathrm{b}}$ Department of Sciences, University of Basilicata, Via Ateneo Lucano, 10, 85100 Potenza, Italy
}

Keywords:

Elastin

Synthetic polypeptide

Amyloid fibers

Thermal analysis

Secondary conformation

\begin{abstract}
A B S T R A C T
Objectives. - This work deals with the conformational and thermal characterization of a synthetic peptide (S4) released during the proteolysis of human tropoelastin by the matrix metalloproteinase-12 that was shown to form amyloid-like fibres under certain conditions.

Materials and methods. - S4 peptides were synthesized by solid-phase methodology and aggregated in solution at $80^{\circ} \mathrm{C}$. Fourier transform-infrared spectroscopy (FT-IR) was used to access the secondary structure. Thermal characterization was performed by thermogravimetric analysis (TGA) and differential scanning calorimetry (DSC).

Results. - The DSC study of the soluble linear peptide S4 in solution in TBS reveals the irreversible aggregation into amyloid fibres. FT-IR, DSC and TGA analyses performed on freeze-dried samples evidence differences between the linear peptide and its associated amyloid-like fibres, both on the conformation and the physical structure. When S4 peptides are aggregated, the prominent conformation scanned by FT-IR is the cross $\beta$-structure, corresponding to TGA to an increase of the thermal stability. Moreover, the DSC thermograms of S4 fibres are characteristic of a highly ordered structure, in contrast to the DSC thermograms of S4 linear peptides, characteristic of an amorphous structure. Finally, the DSC analysis of differently hydrated S4 fibres brings to the fore the specific thermal answer of the wet interfaces of the cross $\beta$-fibres.

Conclusion. - FT-IR and thermal techniques are well suited to evidence conformational and structural differences between the soluble peptide and its amyloid form.
\end{abstract}

\section{R É S U M É}

But de l'étude. - Cette étude concerne la caractérisation physique et conformationnelle d'un peptide synthétique (S4) libéré lors de la protéolyse de la tropoélastine humaine par la métalloprotéase-12 et qui peut former des fibres amyloïdes sous certaines conditions.

Matériaux et méthodes. - Les peptides S4 sont synthétisés en phase solide et agrégés en solution à $80^{\circ} \mathrm{C}$. La spectroscopie infrarouge à transformée de Fourier (IR-TF) est utilisée pour accéder à la structure secondaire. La caractérisation thermique est effectuée par analyse thermogravimétrique (ATG) et par analyse calorimétrique diatherme (ACD).

Résultats. - L'analyse par ACD du peptide soluble et linéaire en solution dans le TBS révèle l'agrégation irréversible en fibres amyloïdes. Les analyses par IR-TF, ACD et ATG sur les échantillons lyophilisés

\footnotetext{
* Corresponding author.

E-mail address: valerie.samouillan@univ-tlse3.fr (V. Samouillan).
} 
mettent en évidence des différences entre la forme soluble et la forme amyloïde, tant au niveau des conformations que de la structure physique. Quand les peptides S4 sont agrégés, la conformation prépondérante révélée par IR-TF est la structure en feuillets $\beta$ croisés, correspondant en ATG à une augmentation de la stabilité thermique. De plus, les thermogrammes ACD des fibres S4 sont caractéristiques d'une structure hautement ordonnée, contrairement aux thermogrammes des peptides S4, associés à une structure amorphe. Enfin, l'analyse ACD des fibres S4 différemment hydratées met en évidence la réponse thermique de l'interface humide des fibres en feuillets $\beta$ croisés.

Conclusion. - Les techniques vibrationnelles et thermiques sont bien adaptées pour mettre en évidence les différences conformationnelles et structurales entre le peptide soluble et sa forme amyloïde.

\section{Introduction}

Elastin, the protein responsible for elasticity of tissues, such as lung, skin and arterial walls consists of a three-dimensional network whose turnover is almost absent under physiological conditions. However, under pathological conditions, the elastolysis by matrix metalloproteinase-12 (MMP-12) can produce biological active fragments as it was shown in photo-damaged skin [1], arteries of atherosclerotic patients [2] and in lung where the elastotic material contains amyloid-like fibres [3].

Moreover, an ex-vivo study evidenced amyloid-like fibres only reacting with a polyclonal antibody to human elastin within atherosclerosis plaques of cerebral arteries of senile patients [4], suggesting the involvement of elastin in the amyloidogenic process. Interestingly, the extensive investigation by mass spectrometry of the cleavage sites of MMP-12 in human skin elastin [5] showed that polypeptide sequences encoded by exon 30 were present in the elastin lysate. Given these finding, we hypothesize that elastin-derived soluble peptides released from elastin by elastolysis might aggregate into amyloid structures in the vicinity of the degraded elastin fibres, that could explain the "elastotic" material described in numerous reports.

For the first time, some polypeptide sequences encoded from exon 30 (the entire polypeptidic sequence encoded by exon 30 ) was previously demonstrated to be amyloidogenic [6], mimicking the elastin fragments produced by elastases were synthesized and studied both at the molecular and supramolecular levels by various spectroscopies, MD simulations and AFM microscopy [7]. Among these peptides, the longest one (S4 peptide) was shown to give rise to amyloid fibres.

The aim of this work is to get an insight into the thermal properties of the soluble, linear peptide S4 (labelled S4 peptides) and its aggregated form (labelled S4 fibres) mainly using thermal analysis (TGA and DSC). DSC is a well-suited technique for the analysis of biological materials both in solution [8-10] and in the condensed state [11-14], the insolubility of some fibres being not an obstacle to the analysis. Combined with TGA, DSC allows to distinguish and to estimate the amount of the different types of water in proteins. Moreover, these techniques reveal ordered and amorphous structures at the mesoscopic level, connecting the molecular level (accessible by vibrational techniques) and the microscopic/macroscopic level (accessible by microscopy and

Table 1

Specific contributions of the techniques used in this study.

\begin{tabular}{ll}
\hline Techniques & Contributions \\
\hline Fourier transform-nfra-red spectroscopy (FT-IR) & Secondary structures \\
Thermogravimetric analysis & Hydration and thermal \\
(TGA) & stability \\
Water sorption & Water affinity \\
Differential Scanning Calorimetry (DSC) & $\begin{array}{l}\text { Ordered and disordered } \\
\text { structures }\end{array}$ \\
\hline
\end{tabular}

turbidimetry), which were already explored in the previous work on S4 [7]. In Table 1, we summarize the different techniques used in this study focusing on the specific contribution of each of them.

It has long been recognized that amyloid fibrils contain a cross$\beta$ spine, with $\beta$-strands perpendicular to the fibril axis $[15,16]$. Atomic structures have been determined by X-ray analysis [17] and by molecular dynamics simulations [18-20] for some of these cross- $\beta$ spines, revealing a pair of $\beta$-sheets mated closely together by intermeshing side chains in what has been termed a steric zipper [17]. The first level in the aggregation of amyloid structures is the rapid and reversible formation of $\beta$-sheets [16]. The slower second step, accompanied by the decrease of entropy, consists in the dehydration and interdigitation of the mating sheet, allowing the formation of the dry amide-stacking hydrogen bonds.

From a medical point of view, thermodynamic and solvation structural properties of amyloidogenic polypeptide sequences could help our understanding on the mechanism of aggregation and the very high insolubility of amyloid fibres also involved in neurodegenerative diseases [21,22]. From a material point of view, the excellent thermal stability and enhanced mechanical properties of amyloid fibres make these structures promising candidates for biomaterial development [23], and their structure-function relationship deserves to be clarified.

\section{Materials and methods}

\subsection{Peptide synthesis and purification}

The S4 peptides (LVGAAGLGGLGVGGLGVPGVGG, molecular weight: $1734 \mathrm{~g} / \mathrm{mol}$ ) were synthesized by solid-phase methodology using an automatic synthesizer APPLIED BYOSYSTEM model $431 \mathrm{~A}$. Fmoc/DCC/HOBT chemistry was used, starting from ( $0.25 \mathrm{mM}$ ) Wang resin (Nova Biochem, Laufelfingen, Switzerland). The Fmocamino acids were purchased from Nova Biochem and from Inbios (Pozzuoli, Italy). The cleavage of the peptides from the resin was achieved by using an aqueous mixture of $95 \%$ trifluoroacetic acid. The S4 peptides were freeze-dried and purified by reversed-phase high performance liquid chromatography and their purity was assessed by electrospray mass spectrometry.

\subsection{Formation of $\mathrm{S} 4$ fibres}

According to previous turbidimetry experiments showing the self-aggregation of S4 into amyloid-like structures [7], S4 peptides were dissolved in TBS buffer [Tris (50 mM), $\mathrm{NaCl}(1.5 \mathrm{M})$, and $\mathrm{CaCl}_{2}(1.0 \mathrm{mM}), \mathrm{pH}$ 7] with a concentration of $30 \mathrm{mg} / \mathrm{mL}$ $(17 \mathrm{mM})$; the solution was stirred at $80^{\circ} \mathrm{C}$ for $3 \mathrm{~h}$ in order to precipitate $\mathrm{S} 4$ peptides into S4 fibres. Once formed, S4 fibres were separated from the solution by 3 cycles of centrifugation $(15,000 \mathrm{rpm}, 5 \mathrm{~min})$ and washed in pure distilled water prior the freeze-drying process.

\subsection{Fourier transform-infrared spectroscopy (FT-IR)}

Fourier transform-infrared spectroscopy/attenuated total reflectance (FT-IR/ ATR) spectra were collected using a Nicolet 5700 FTIR (THERMO FISHER SCIENTIFIC, Waltham, MA) equipped in ATR device equipped with a $\mathrm{KBr}$ beam splitter and a MCT/B detector. Spectra were recorded over the region of $4000-450 \mathrm{~cm}^{-1}$ with a spectral resolution of $4 \mathrm{~cm}^{-1}$ and 64 accumulations. The ATR accessory used was a Smart Orbit equipped with a type IIA diamond crystal (refractive index 2.4). A single-beam background spectrum was collected from the clean diamond crystal before each experiment and this background was subtracted from the spectra. 
Fourier-self-deconvolution (FSD) of the infrared spectra that allows resolution of several overlapping bands [24] was performed in the amide I/II region using Omnic software (THERMO FISHER SCIENTIFIC, Waltham, MA) to extract the peak maxima. The decomposition of the amide I/II bands on the renormalized spectrum was then performed with a Gaussian curve fitting procedure.

\subsection{Thermogravimetry analysis (TGA)}

Analyses were performed in triplicate on freeze-dried samples (initial weight $5 \mathrm{mg}$ ) set in alumina pans between 25 and $650^{\circ} \mathrm{C}$ at $10^{\circ} \mathrm{C} / \mathrm{min}$ under $\mathrm{N}_{2}$ atmosphere using a TGA Q50 (TA INSTRUMENTS, New Castle, DE).

\subsection{Water sorption}

Initial freeze-dried samples were equilibrated on $\mathrm{MgN}_{2} \mathrm{O}_{6} \cdot 6 \mathrm{H}_{2} \mathrm{O}$ saturated solutions at $25{ }^{\circ} \mathrm{C}$ (corresponding to a 53\% relative humidity). Samples were weighted with a Mettler microbalance after different times of equilibrium. After measurements samples were completely dehydrated over $\mathrm{P}_{2} \mathrm{O}_{5}$ overnight at $105^{\circ} \mathrm{C}$ and weighted again to determine the mass of the dry samples and the mass of water by difference. The hydration level was defined as the mass of water divided by the mass of the hydrated sample.

\subsection{Differential scanning calorimetry (DSC)}

Analyses were performed using a DSC Pyris calorimeter (PERKIN ELMER, Waltham, MA). The calorimeter was calibrated using cyclohexane and indium as standards, resulting in a temperature accuracy of $\pm 0.1^{\circ} \mathrm{C}$ and an enthalpy accuracy of $\pm 0.2 \mathrm{~J} / \mathrm{g}$. The sample cell was purged with helium and the cooling and heating scan rates were 10 or $20^{\circ} \mathrm{C} /$ min depending on the experiments.

An amount of $10 \mu \mathrm{L}$ of S4 peptide solutions [ $2 \mathrm{mM}$ in solution in TBS buffer Tris (50 mM), $\mathrm{NaCl}(1.5 \mathrm{M})$, and $\mathrm{CaCl}_{2}(1.0 \mathrm{mM}), \mathrm{pH}$ 7] were sealed in $15 \mu \mathrm{L}$ aluminium hermetic pans. Experiments, done in triplicate, were performed between 10 and $90{ }^{\circ} \mathrm{C}$ in the heating and cooling mode at $10^{\circ} \mathrm{C} / \mathrm{min}$.

Freeze-dried S4 peptides and freeze-dried S4 fibres, $5 \mathrm{mg}$ in weight, were sealed into non-hermetic aluminium pans. Experiments, done in triplicate, were performed between 5 and $225^{\circ} \mathrm{C}$ with a heating rate of $20^{\circ} \mathrm{C} / \mathrm{min}$.

Hydrated S4 fibers, 2-10 mg in weight, were sealed into hermetic aluminium pans. Samples were first cooled at $-50^{\circ} \mathrm{C}$ at $10^{\circ} \mathrm{C} / \mathrm{min}$ and equilibrated at $-50{ }^{\circ} \mathrm{C}$ during $5 \mathrm{~min}$. Experiments, done in triplicate, were recorded in the heating mode between -50 and $30-70{ }^{\circ} \mathrm{C}$ (depending on the hydration level) with a heating rate of $20{ }^{\circ} \mathrm{C} / \mathrm{min}$.

\section{Results}

\subsection{DSC analysis of S4 peptides in solution}

During the first heating, the thermogram of S4 peptides in solution (Fig. 1) is characterized by the $\Delta \mathrm{C}_{\mathrm{p}}$ heat capacity step at $37^{\circ} \mathrm{C}$ and two sharp exothermic peaks at $61{ }^{\circ} \mathrm{C}$ and $78^{\circ} \mathrm{C}$, superimposed on $\Delta \mathrm{C}_{\mathrm{p}}$ heat capacity steps; in contrast, the

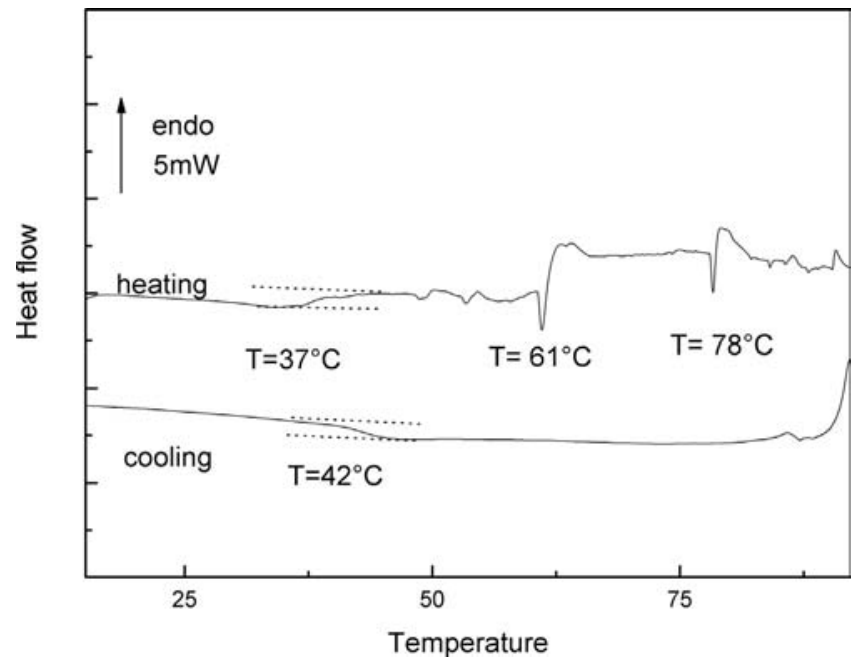

Fig. 1. DSC thermograms of S4 peptides in solution ( $2 \mathrm{mM}$ ) (heating and cooling runs). thermogram recorded during cooling does not present any transition in the $80-60{ }^{\circ} \mathrm{C}$ temperature zone (successive heating scans, not shown here, are also devoid of such sharp exothermic transitions), demonstrating the irreversibility of these two transitions. The only event recorded during the cooling run is a well-defined $\Delta \mathrm{C}_{\mathrm{p}}$ heat capacity step at $T=42{ }^{\circ} \mathrm{C}$, reproducible in successive heating/cooling cycles.

\subsection{FT-IR spectroscopy of S4 peptides and S4 fibres in the freeze-dried state}

The FT-IR spectra of S4 peptides and S4 fibres (Fig. 2) are typical of polypeptides and proteins, exhibiting the amide $\mathrm{A}$ (free and $\mathrm{H}$ bonded $\mathrm{O}-\mathrm{H}$ stretching and $\mathrm{N}-\mathrm{H}$ stretching), amide $\mathrm{I}(\mathrm{C}=\mathrm{O}$ stretching), amide II ( $\mathrm{C}-\mathrm{N}$ stretching and $\mathrm{N}-\mathrm{H}$ bending), and amide III ( $\mathrm{N}-\mathrm{H}$ in plane deformation) bands. Some distinct features can be observed on these global spectra, particularly the narrowing and the shift (from 3289 to $3281 \mathrm{~cm}^{-1}$ ) of the main band of amide A band in S4 fibres as well as the narrowing and the shift (from 1644 to $1624 \mathrm{~cm}^{-1}$ ) of the amide I band.

The amide $\mathrm{A}$ band includes the free and bonded absorptions of $\mathrm{OH}$ and $\mathrm{NH}$ groups [25]. As already observed in $\alpha$-elastin, the shift toward lower wave numbers of the amide A band in S4 fibres bands is linked to the increase in the strength of the hydrogen bonds and phase structure [25].

Since the amide I-II region consists of several bands strongly dependent on secondary conformations, it was subjected to curve fitting in order to resolve the various underlying and overlapping spectral features that contribute to this complex region [26-30]. The decomposed FT-IR spectra of the amide I-II region are presented in Fig. 3.

The amide I region (corresponding to the stretching vibrations of the $\mathrm{C}=\mathrm{O}$ group of the peptide backbone) of $\mathrm{S} 4$ peptides contains a main component at $1633 \mathrm{~cm}^{-1}$, ascribed to bonded $\beta$ turns/ pleated $\beta$-sheets. This component together with the additional ones observed at 1694 and 1680 are indicative of anti-parallel $\beta$-sheet conformations and $\beta$ turns, respectively [7,27]. Since the bands comprised between 1640 and 1660 are generally associated with unordered conformations and water absorption [7,24,29], the large component detected at $1651 \mathrm{~cm}^{-1}$ is certainly due to an overlapping of these contributions. It is also noteworthy that nonhydrogen bonded $\mathrm{C}=\mathrm{O}$ groups absorb in the $1667-1661 \mathrm{~cm}^{-1}$ range [7], confirming the presence of PPII conformation in S4 peptide as already revealed in solution by $\operatorname{CD}[7,29]$. The decomposition of the amide II band yields two main components

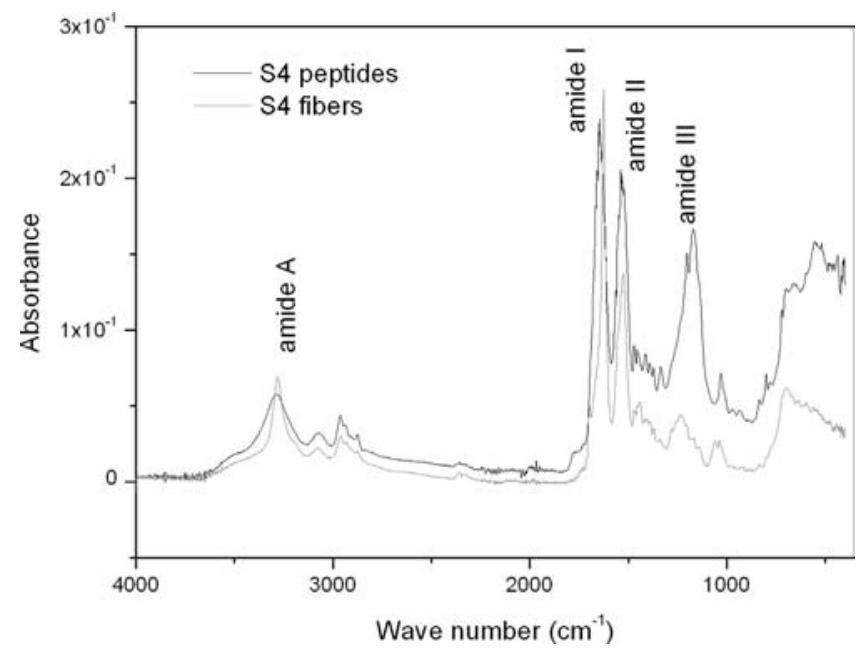

Fig. 2. FT-IR/ATR spectra of freeze-dried S4 peptides and S4 fibers. 

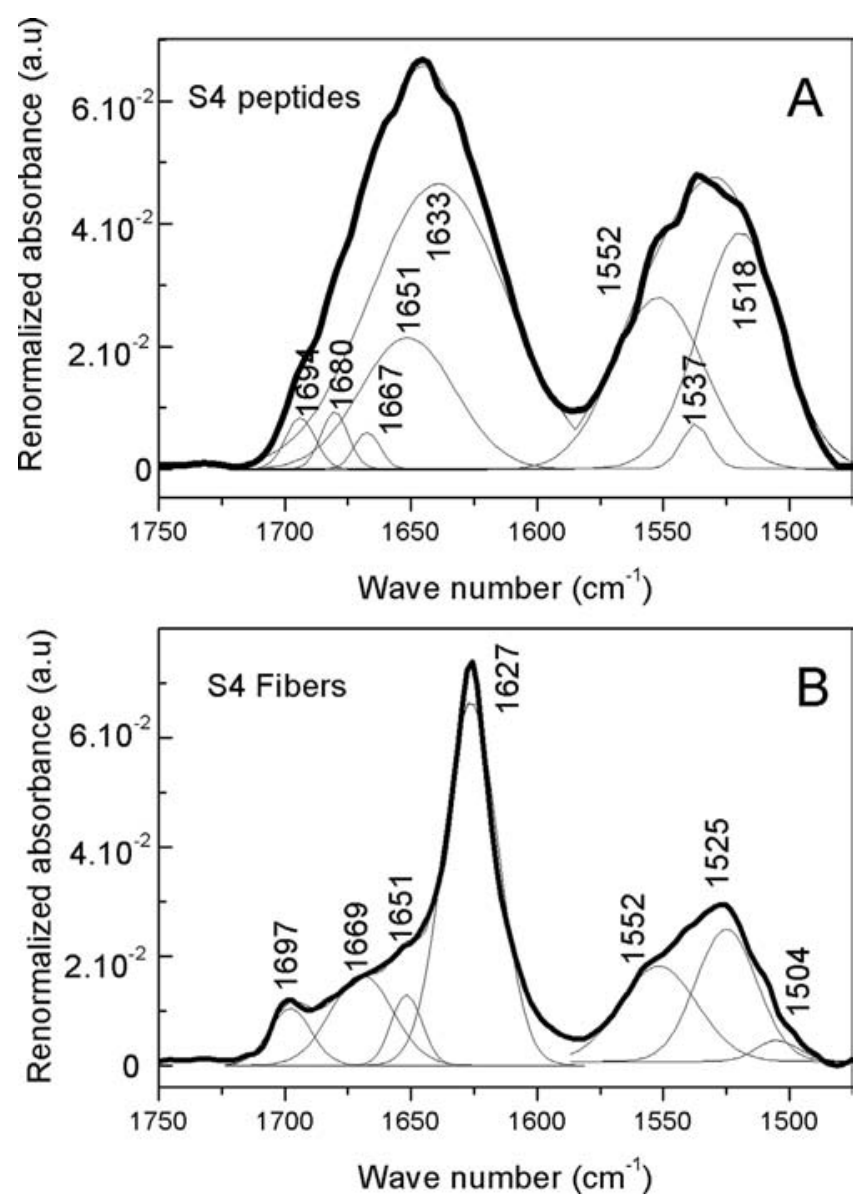

Fig. 3. Decomposed FT-IR spectrum of S4 peptides (A) and S4 fibers (B) in the amide I-II zone (bold line: experimental curve; fine lines: decomposition into Gaussian peaks and sum of the Gaussian peaks).

at 1552 and $1518 \mathrm{~cm}^{-1}$, which are considered representative of the presence of the $\beta$-sheet conformation [7]. The band at $1537 \mathrm{~cm}^{-1}$ could be tentatively assigned to the unordered component [31]. We propose for $\mathrm{S} 4$ peptides in the freeze-dried state a dominance of $\beta$-structures together with unordered and PPII conformations.

The amid I region of S4 fibres is very distinct from the amid I region of S4 peptides, with a prominent component at $1627 \mathrm{~cm}^{-1}$ ascribed to intermolecular $\beta$-sheets in cross $\beta$-structures [32], together with a band of increasing intensity at $1697 \mathrm{~cm}^{-1}$, which is typical of the anti-parallel $\beta$-sheet conformation. The two minor bands at 1651 and $1669 \mathrm{~cm}^{-1}$ can be attributed to unordered conformations/water absorption [7,29] and $\beta$ turns [26], respectively. The predominance of the cross $\beta$-structure in S4 fibres is attested by the presence of two main components in the amide II region at 1552 and $1525 \mathrm{~cm}^{-1}$, that are representative of the $\beta$-sheet conformation [7,32].

3.3. Thermogravimetric analysis of S4 peptides and S4 fibres in the freeze-dried state

Thermogravimetric (TG) and temperature/derivative (DTG) plots of freeze-dried S4 peptides and freeze-dried S4 fibres are shown in Fig. 4. The mass decrement during the heating process was determined from TG curves and the temperature of the maximum speed of the process $\left(\mathrm{T}_{\max }\right)$ was determined from the maximum of the DTG curves. The global trend of the two TG plots corresponds to the classical thermal behaviour of freeze-dried proteins [33,34]. The first stage (between 25 and $200{ }^{\circ} \mathrm{C}$ ) is generally connected with the evaporation of water absorbed to the

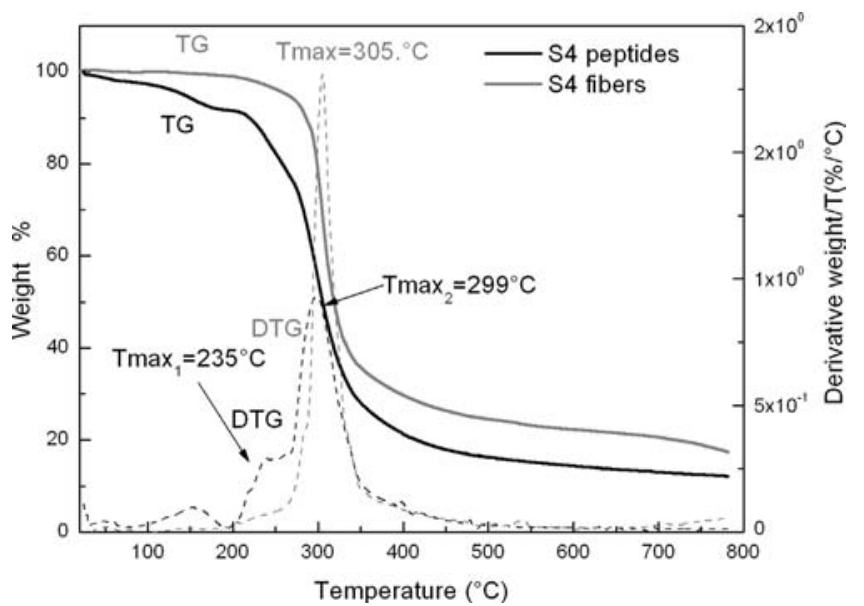

Fig. 4. TGA thermograms (TG) and temperature derivative (DTG) thermograms of freeze-dried S4 peptides and freeze-dried S4 fibers.

protein, and corresponds to 8.5 and $1.36 \%$ of the total mass for S4 peptides and $\mathrm{S} 4$ fibres, respectively, meaning that freeze-drying of S4 fibres is more efficient than freeze-drying of S4 peptides.

The second stage occurring between 200 and $500{ }^{\circ} \mathrm{C}$ is associated with the degradation of the sample, namely the progressive deamination, decarboxylation and depolymerization arising from the breaking of polypeptide bonds. The degradation of S4 peptides consists of two well-marked steps as shown by two maxima on the DTG plots at $T_{\max 1}=235$ and $T_{\max 2}=299{ }^{\circ} \mathrm{C}$, in contrast with the degradation of S4 fibres that occurs in a narrow temperature range with a single maximum at $T_{\max }=305.3^{\circ} \mathrm{C}$.

3.4. Water sorption experiments on S4 peptides and S4 fibres in the freeze-dried state

Water sorption experiments at $53 \% \mathrm{RH}$ were performed at $25{ }^{\circ} \mathrm{C}$ (Fig. 5) in order to obtain information on the water/polypeptides affinity first revealed by TGA.

Under these conditions of humidity, we can notice that S4 fibres can adsorb up to $85 \%$ of water in contrast to $\$ 4$ peptides that cannot adsorb more than $19 \%$ of water. As revealed by TGA, it is noteworthy that the freeze-drying procedure is more efficient on S4 fibres than on S4 peptides, leading to initial freeze-dried states with $2 \%$ and $8 \%$ of water, respectively.

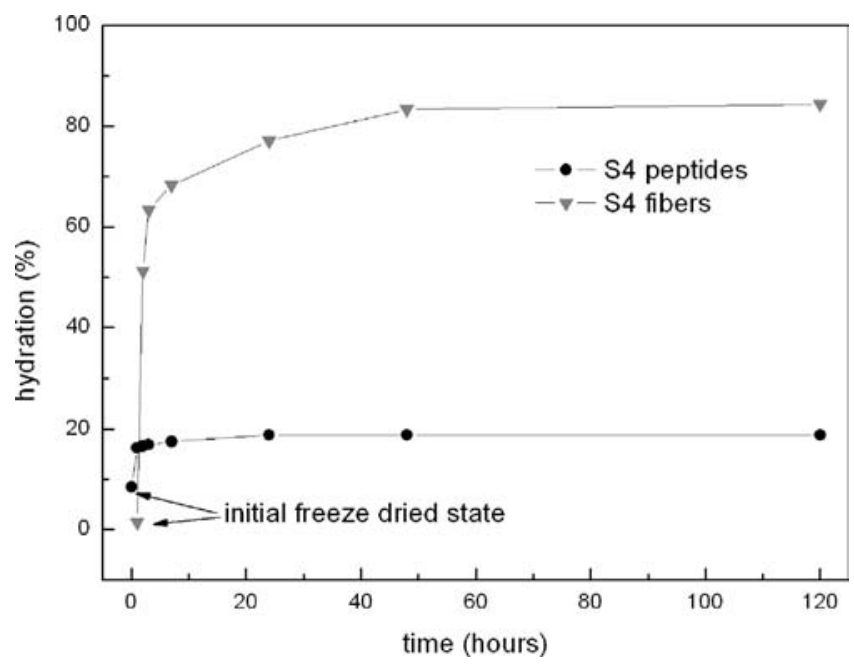

Fig. 5. Water sorption of S4 peptides and S4 fibers under $53 \% \mathrm{RH}$ at $25^{\circ} \mathrm{C}$. 


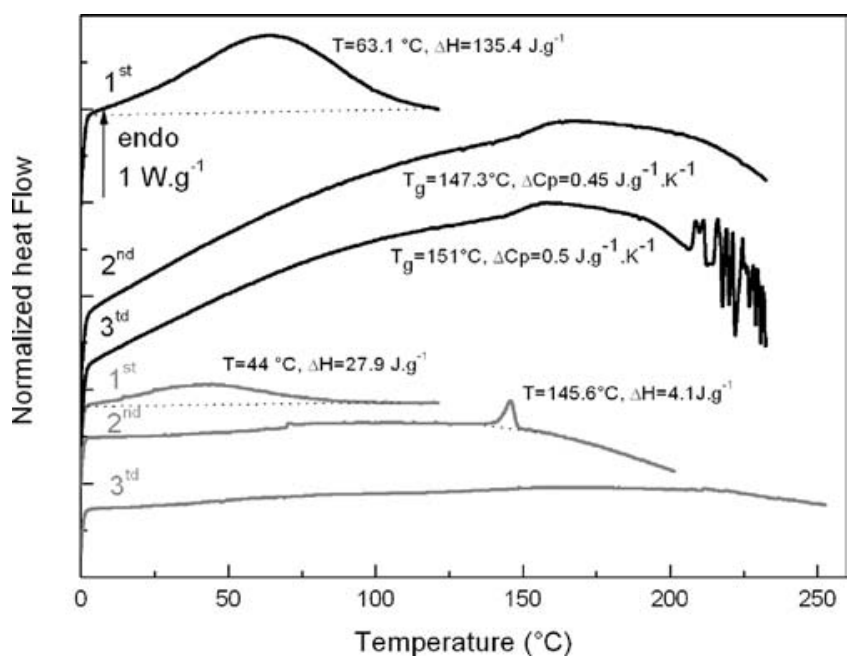

Fig. 6. DSC thermograms of freeze-dried S4 peptides and freeze-dried S4 fibers (first, second and third heating runs).

\subsection{DSC analysis of S4 peptides and S4 fibres in the freeze-dried state}

Thermograms of freeze-dried S4 peptides and freeze-dried S4 fibres were recorded in the heating mode between 5 and $120^{\circ} \mathrm{C}$ (first run) and between 5 and $225^{\circ} \mathrm{C}$ on the successive runs (Fig. 6).

In the case of freeze-dried S4 peptides, the broad endothermic peak observed on the first scan at $63.1{ }^{\circ} \mathrm{C}$ may be considered as the first order transition commonly observed in a broad class of hydrated biopolymers. By analogy with previous works [33,35,36], this endothermic event is attributed to the evaporation of bound water, and the value of the enthalpy $(\Delta \mathrm{H}=135 \mathrm{~J} / \mathrm{g})$ is coherent with an amount of bound water comprised between 8 and $10 \%$ as measured both by TGA and dehydration over $\mathrm{P}_{2} \mathrm{O}_{5}$ at $105{ }^{\circ} \mathrm{C}$. On the second thermogram, the specific thermal answer of wholly dehydrated $\mathrm{S} 4$ peptides can be observed. The presence of a glass transition at $147.3{ }^{\circ} \mathrm{C}\left(\Delta \mathrm{C}_{\mathrm{p}}=0.45 \mathrm{~J} / \mathrm{g} / \mathrm{K}\right)$, reversible on successive scans, underlines the fact that freeze-dried S4 peptides possess an amorphous region, with a lack of long-range order, like elastin $[37,38]$. As already observed by TGA, the degradation of S4 peptides begins above $210^{\circ} \mathrm{C}$.

In the case of freeze-dried S4 fibres, the endothermic event associated with the evaporation of water is weaker $(\Delta H=27.9 \mathrm{~J} / \mathrm{g})$ than the event reported for S4 peptides. The ratio between enthalpies is roughly the same as the ratio between the total amounts of bound water measured by TGA and dehydration over $\mathrm{P}_{2} \mathrm{O}_{5}$ at $105^{\circ} \mathrm{C}$.

The main event detected on the second thermogram is the sharp endothermic peak at $145.6{ }^{\circ} \mathrm{C}$ associated to an order $\rightarrow$ disorder transition, which can be considered as to the thermal signature of amyloids fibres. The sharpness of this first order transition is indicative of a highly cooperative process. This transition, not observed on the third scan, is irreversible.

\subsection{DSC analysis of S4 fibres in the hydrated state}

Freeze-dried S4 fibres $5 \mathrm{mg}$ in weight were equilibrated over $\mathrm{MgN}_{2} \mathrm{O}_{6} \cdot 6 \mathrm{H}_{2} \mathrm{O}$ saturated solutions at $25^{\circ} \mathrm{C}$ (relative humidity 53\%) until the water uptake reached a maximum. The total hydration level of the samples was evaluated by gravimetry, and was equal to 84.3\% under these conditions of humidity. Different hydration levels were obtained equilibrating the fully hydrated samples over $\mathrm{KOH}$ saturated solutions at $25{ }^{\circ} \mathrm{C}$ (relative humidity 8\%) during different times, allowing a gradual dehydration of the samples. Complete dehydration was obtained by a heating at $60{ }^{\circ} \mathrm{C}$ during

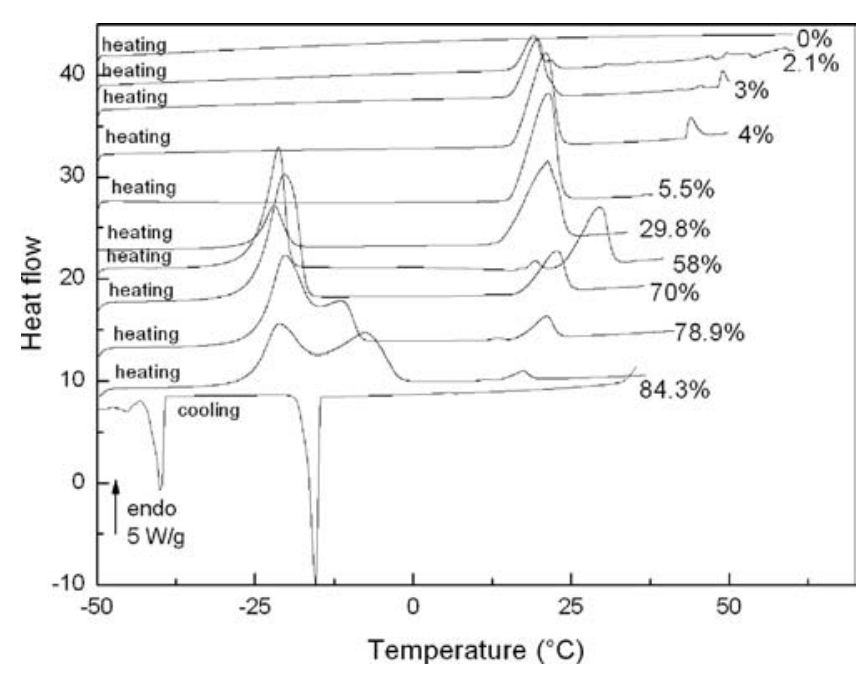

Fig. 7. DSC thermograms of S4 fibers at various hydration levels (cooling and heating runs).

$10 \mathrm{~min}$. The thermograms of the differently hydrated samples recorded in the heating mode are shown in Fig. 7. For the sake of clarity, only one cooling thermogram (corresponding to the sample containing $84.3 \%$ of water) has been superimposed in this figure.

For high hydration levels, a part of water absorbed in the sample is able to crystallize as shown by the exothermic events at $-14{ }^{\circ} \mathrm{C}$ and $-39{ }^{\circ} \mathrm{C}$ on the first cooling thermogram of the Fig. 7. On the successive heating thermogram, the melting of this crystallized water gives rise to endothermic phenomena between -30 and $0^{\circ}$. This melting peak consists of two contributions for high hydration levels, suggesting the presence of two kinds of ice in this case. For lower hydration levels (70\%, 58\% and 29.8\%), only the low temperature peak is observed; in previous studies on water insoluble biological polymers, this peak was attributed to freezing bound water [39], corresponding to loosely bound water adsorbed on polymer having a certain kind of crystalline structure which may be the same as the structure of natural ice [40]. The second important event detectable on the thermograms of differently hydrated S4 fibres is the endothermic peak occurring between 15 and $35{ }^{\circ} \mathrm{C}$, for hydration levels comprised between 84.3 and $2.1 \%$, vanishing for completely dehydrated samples, and indicative of the transition from an ordered to an unordered structure.

\section{Discussion}

\subsection{Thermal behaviour of S4 peptides in solution - irreversible aggregation}

In the case of S4 peptides, the first heating thermogram reported in Fig. 1 gets an insight into the possible aggregation mechanism into S4 amyloids fibres evidenced in a previous work by turbidimetry and biochemical tests [7]. Firstly, the positive $\Delta C_{p}$ contribution at $37^{\circ} \mathrm{C}$ is certainly associated with the progressive destabilization of the polyproline II (PII) conformation from 0 to $60{ }^{\circ} \mathrm{C}$ as it was evidenced by circular dichroism [7], shifting the equilibrium between PPII, unordered structures and $\beta$ turns towards $\beta$ turns preferential conformation. It must be pointed out that PPII is a flexible structure devoid of intramolecular hydrogen bonds that can easily interchange with other conformations [7].

Comparing the special feature of the sharp exothermic peaks occurring at 61 and $78{ }^{\circ} \mathrm{C}$ with the DSC-monitored aggregation of insulin [41], $\beta$-lactoglobulin [42] and $\beta 2$-microglobulin [43] into amyloid fibres, we propose to ascribe them to the formation of $\beta$-sheets and cross $\beta$-structures, leading to the irreversible 
aggregation of the S4 peptides into S4 fibres. This multi-step, irreversible aggregation mainly driven by hydrophobic interactions involves both formation of hydrogen bonds into $\beta$-sheets structures $[41,42]$, dipoles-dipoles interactions into the steric zipper and breakdown of hydrogen bonds (rearrangement of water around the peptide, expulsion of water at the $\beta$-sheet- $\beta$ sheet interface of the steric zipper); the total area of the exothermic peaks is estimated at $-6 \mathrm{~J} / \mathrm{g}$ (where the mass corresponds to the mass of dry S4 peptides); this net negative enthalpy is certainly due to a total increase of the global hydrogen bonds network density and the positive contribution of Van der Waals interactions at the dry interface of the steric zipper [16-18]. This assumption is well supported by turbidimetry experiments, suggesting for S4 peptides an irreversible inverse-temperature phase transition above $60{ }^{\circ} \mathrm{C}$. The reorganization of water molecules around the $\beta$-sheets structure could explain the associated variations of the heat capacity, since the heat capacity change originates primarily from the hydrogen-bonding properties of water near the protein surface $[44,45]$.

\subsection{Conformation of S4 peptides and S4 fibres - relation with thermal stability}

Our FT-IR results in good agreement with the structural data on amyloid fibrils; while S4 polypeptides adopt a wide distribution of conformations (PPII, unordered conformations, $\beta$-sheets and $\beta$ turns), S4 fibres consist mainly of intermolecular $\beta$-sheets in cross $\beta$-structures, with an increasing strength of the involved hydrogen bonds.

The multiplicity of the thermal degradation evidenced by TGA on S4 peptides can be correlated with the multiplicity of the secondary structures revealed by FT-IR analysis, the unordered structure being less stable than the highly ordered, high hydrogen bonded $\beta$-sheets. Moreover, it is noteworthy that even the degradation of the more stable component in S4 peptides occurs at lower temperature $\left(T=299{ }^{\circ} \mathrm{C}\right)$ than in S4 fibres. This thermal stabilization of $\beta$-sheets in the S4 fibres can be related to their organization into cross $\beta$-spines with steric zippers, with a densification of hydrogen bonds.

\subsection{Physical structure of S4 peptides and S4 fibres in the freeze-dried state}

The amorphous character of S4 peptides is evidenced by DSC with the presence of a glass transition without any endothermic peak that would be indicative of an ordered structure. This lack of long-range order is due to the coexistence of unordered conformations, labile $\beta$ turns and PPII conformations as evidenced by FT-IR analysis in the dry state. It is noteworthy that the glass transition temperature of S4 peptides is close to the glass transition temperature of the polypeptide encoded by exon 10 of human tropoelastin $\left(T_{\mathrm{g}}=144.2^{\circ} \mathrm{C}, M_{\mathrm{w}}=2100.5 \mathrm{~g} / \mathrm{mol}\right)$ [10], and lower than recombinant freeze-dried human tropoelastin $\left(T_{\mathrm{g}}=190^{\circ} \mathrm{C}\right)$ [26] or freeze-dried elastin $\left(T_{\mathrm{g}}=200^{\circ} \mathrm{C}\right)$ [30].

In agreement with vibrational and thermogravimetric results, the thermal transitions of S4 fibres are very distinct from the S4 peptides ones. The sharp endothermic peak at $145.6^{\circ} \mathrm{C}$, indicative of the cooperative melting of a long-range ordered structure can be addressed to the thermal signature of amyloid fibres, forming highly ordered cross $\beta$-structures with intra- and intermolecular $\beta$-sheets that extend throughout the entire length of the fibre. Such an endothermic event has already been observed by DSC in the hydrated state for the fibrils of the N47A mutant of the R-spectrin SH3 [13]. The temperature of this peak is indicative of an important stabilization of the ordered $\beta$-sheets structure when S4 forms fibres. It must be pointed out that the enthalpy of this endothermic event $(\Delta \mathrm{H}=4 \mathrm{~J} / \mathrm{g}$ ) is in the same range of order than freeze-dried collagen type I $[33,46]$, which can be also considered as a "crystalline" biopolymer possessing a very long-range order.

\subsection{Physical structure of S4 fibres in the presence of water}

The first important point concerns the difference of solubility of S4 peptides and S4 fibers: if S4 peptides are soluble in water like a wide class of linear polypeptides, once formed S4 fibres are insoluble and cannot be studied in solution. That is the reason why S4 fibres were analyzed in this work at different degrees of hydration.

The very distinct water affinity of S4 peptides and S4 fibres in the freeze-dried state revealed by water sorption experiments is quite striking at first glance because of the same chemical composition of both samples. From a polymer point of view, it can appear paradoxical since S4 peptides possess unordered conformations in contrast to S4 fibres that are quasi-wholly organized in ordered cross $\beta$-structures. Interestingly, a large amount of water can be trapped in this highly ordered structure, as already observed for other systems, such as hydrogels [40], multilamellar vesicles [47] and silk-keratin composites [48] constituted of numerous interstices, bringing to the fore different states of water (freezing free water, freezing bound water and non-freezing bound water).

In the case of S4 fibres, the trapping of a large quantity of water must be connected to the definition of the wet interfaces between $\beta$-sheets of the outside faces of the pair of sheets revealed by structural analysis of amyloid fibres [16]. As a matter of fact, there are two distinctly different interfaces between $\beta$-sheets of the cross $\beta$-spine: a dry, dewetted interface between the paired sheets engaged into the steric zipper, in contrast to the highly hydrated external faces exposed to solvent [16].

The content of crystallized water into differently hydrated S4 fibres was estimated from the heating thermograms (Fig. 8) as the ratio of the melting enthalpy $\Delta \mathrm{H}$ of the hydrated sample and the melting enthalpy of bulk water [49] (333.55 J/g) and reported in Fig. 8. By difference, the uncrystallized water amount was also evaluated and reported in Fig. 8. In contrast to the amount of crystallized water that increases with the hydration level, the content of uncrystallized water reaches a maximum for hydration levels comprised between 30 and 70\%. In this range of hydration, approximatively $15 \%$ of water molecules are tightly bound to S4 fibres. We have also reported in Fig. 8 the enthalpy ( $\Delta \mathrm{H}$ fibres)

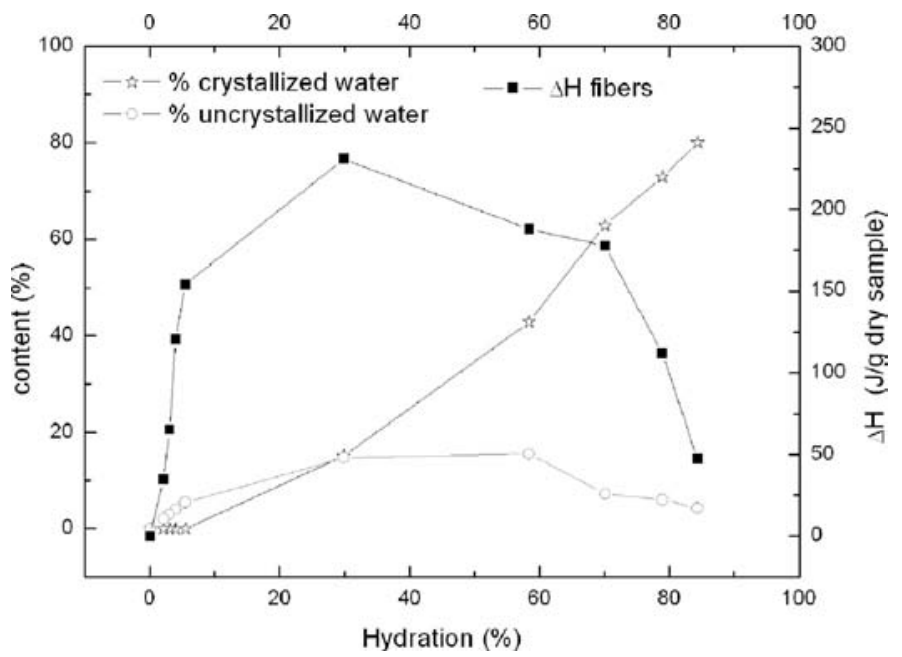

Fig. 8. Amounts of crystallized and uncrystallized water in S4 hydrated fibers and enthalpy of the second endothermic peak as a function of the total hydration of S4 fibers computed from Fig. 7. 
normalized to the mass of dry fibres, corresponding to the second endothermic event detected between 15 and $35^{\circ} \mathrm{C}$ on the thermograms of Fig. 7, associated to an ordered structure. The enthalpy of this event sharply increases between 0 and $5 \%$ of hydration, meaning that uncrystallized/bound water is essential for the stabilization of this structure. Interestingly, the enthalpy is maximum when the amount of uncrystallized water is maximum, confirming this assumption. It is clearly shown in Fig. 8 that an excess of crystallized water destabilizes this ordered structure, resulting also in a decrease of bound water. Water, in this case possesses a peculiar behaviour, very distinct from what observed for globular proteins [49], where the amount of uncrystallized water increases with increasing water content, reaching a maximum for high hydration contents. This endothermic event can be considered as the thermal answer of the wet interface of the cross $\beta$-fibres, mainly due to the disruption of hydrogen bonds between water and polypeptidic chains when the temperature increases.

\section{Conclusion}

In contrast to tropoelastin that coacervates to give rise to native fibrillar structures, with an equilibrium at the conformational level between unordered conformations, labile PPII and $\beta$ turns, $\beta$ strands and $\alpha$-helices, essential for its biological function, the synthetic derived-elastin peptide S4 mimicking the released fragment from elastolysis by MMP-12 self-assembles into $\beta$ structure-rich amyloid-like fibres [7], which shows a greater degree of conformational restriction than the native elastin structure. In this work, we attempted to get an insight into the physical structure and water affinity of this peptide in its linear state and its aggregate state, since few studies in the literature have reported thermodynamics of amyloid fibre formation and thermal characterization of amyloid fibres.

Firstly, it was shown that the formation of irreversible aggregates when temperature is raised up in S4 polypeptide solution could be monitored by DSC, corroborating the previous turbidimetry assays. This multi-step mechanism is associated with a net negative variation of enthalpy, due to a net positive increase of H-bonds and Van der Waals interactions. Further experiments performed at different concentrations and different scan rates will be necessary to quantitatively estimate the balances of changes in enthalpy and entropy. Moreover, it will be essential to evaluate the influence of the medium (in peculiar the role of calcium) on this aggregation phenomenon in order to correlate it with pathologic conditions.

In the condensed state, the thermal signature of S4 precipitated fibres is completely distinct from the one of the linear polypeptides; the former is highly stable and ordered, while the latter is less stable, without any long-range order. These radically distinct features at the ultrastructural level are well correlated with the major changes detected at the conformational level by FT-IR analysis.

Finally, DSC is well suited to evidence the peculiar thermal signature of the wet interfaces of the outside faces of the pair of sheets structure of amyloids fibrils first proposed by Nelson et al. [16] on structural analysis of elongated microscrystals.

\section{References}

[1] Chung JH, Seo JY, Lee MK, Eun HC, Lee JH, Kang S, et al. Ultraviolet modulation of human macrophage metalloelastase in human skin in vivo. J Inv Dermatol 2002;119:507-12.

[2] Varadi DP. Studies on the chemistry and fine structure of elestic fibers from normal adult skin. J Inv Dermatol 1972;59:238-46.

[3] Fan K, Nagle WA. Amyloid associated with elastin-staining laminar aggregates in the lungs of patients diagnosed with acute respiratory distress syndrome. BMC Pulm Med 2002;2:5.

[4] Doostkam S, Bohl JR, Sahraian A, Mahjoor AA. Amyloid deposits in senile vertebral arteries, immunohistological and ultrastructural findings. Pakistan J Biol Sci 2008;11:1852-5.
[5] Taddese S, Weiss AS, Neubert RH, Schmelzer CE. In vitro degradation of human tropoelastin by MMP-12 and the generation of matrikines from domain 24 . Matrix Biol 2010;22(Suppl 1):E56-66.

[6] Tamburro AM, Pepe A, bochicchio B, Quaglino D, Ronchetti IP. Supramolecular amyloid-like assembly of the polypeptide sequences coded by exon 30 of human tropoelastin. J Biol Chem 2005;280:2682-90.

[7] bochicchio B, Pepe A, Delaunay F, Lorusso M, Baud S, Dauchez M. Amyloidogenesis of proteolytic fragments of human elastin. J Royal Soc Chem 2013. doi:10.1039/b00000000x.

[8] Luan CH, Parker TM, Channe Gowda D, urry DW. Hydrophobicity of amino acid residues: differential scanning calorimetry and synthesis of the aromatic analogues of the polypentapeptide of elastin. Biopolymers 1992;32:1251-61.

[9] Rodriguez-Cabello JC, Alonso M, Perez T, Herguedas NM. Differential scanning calorimetry study of the hydrophobic hydration of the elastin-based polypentapeptide. Poly(VPGVG), from deficiency to excess of water. Biopolymers 2000;54:282-8.

[10] Tintar D, Samouillan V, Dandurand J, Lacabanne C, Pepe A, Bochicchio B, et al. Human tropoelastin sequences: dynamics of polypeptide coded by exon 6 in solution. Biopolymers 2009;91:943-52.

[11] Megret C, Guantieri V, Lamure A, pieraggi MT, Lacabanne C, tamburro AM. Phase transitions and chain dynamics, in the solid state, of a pentapeptide sequence of elastin. Int J Biol Macromol 1992;14:45-9.

[12] Rodriguez-Cabello JC, Alonso M, Diez MI, Caballero MI, Herguedas NM. Structural investigation of the poly(pentapeptide) of elastin, poly(GVGVP), in the solid state. Macromol Chem Phys 1999;200:1831-8.

[13] Morel B, Varela L, Conejero-Lara F. The thermodynamic stability of amyloid fibrils studied by differential scanning calorimetry. J Phys Chem B 2010;114: 4010-9.

[14] Samouillan V, Dandurand J, Nasare L, Badimon L, Lacabanne C, Llorente-Cortés $\mathrm{V}$. Lipid loading of human vascular smooth muscle cells induces changes in tropoelastin protein levels and physical structure. Biophys J 2012;103: 532-40.

[15] Heise H, Celej MS, Becker S, Riedel D, Pelah A, Kumar A, et al. reveals structural differences between fibrils of wild-type and disease-related A53T mutant $\alpha$ synuclein. J Mol Biol 2008;380:444-50.

[16] Nelson R, Sawaya MR, Balbirnie M, Madsen AØ, Riekel C, Grothe R, et al. Structure of cross- $\beta$ spine of amyloid-like fibrils. Nature 2005;435:773-8.

[17] Nelson R, Eisenberg D. Recent atomic models of amyloid fibril structure. Cur Opin Struct Biol 2006;16:260-5.

[18] Esposito L, Pedone C, Vitagliano L. Molecular dynamics analyses of cross- $\beta$ spine steric zipper models: $\beta$-sheet twisting and aggregation. PNAS 2006; 103:11533-8.

[19] Xu W, Su H, Zhang JZ, Mu Y. Molecular dynamics simulation study on the molecular structures of the amylin fibril models. J Phys Chem B 2012;116: 13991-9.

[20] Cheon M, Chang I, Hall CK. Spontaneous formation of twisted A $\beta 16-22$ fibrils in large scale molecular dynamics simulations. Biophys J 2011;101:2493-501.

[21] Serpell LC. Alzheimer's amyloid fibrils: structure and assembly. Biochim Biophys Acta 2000;1502:16-30.

[22] Toyama BH, Weissman JS. Amyloid structure: conformation diversity and consequences. Ann Rev Biochem 2011;80:552-85.

[23] Schleeger M, vanden Akker C, Deckert-Gaudig T, Deckert V, Velikov KP, Koenderink G, et al. Amyloid: from molecular structure to mechanical properties. Polymer 2013;54:2473-88.

[24] Hu X, Kaplan D, Cebe P. Determining beta-sheet crystallinity in fibrous proteins by thermal analysis and infrared spectroscopy. Macromol 2006; 39:6161-70.

[25] Popescu MC, Vasile C, Craciunescu O. Structural analysis of some soluble elastins by means of FT-IR and 2D IR correlation spectroscopy. Biopolymers 2010;93:1072-84.

[26] Hu X, Wang X, Rnjak J, Weiss A, Kaplan DL. Biomaterials derived from silktropoelastin protein systems. Biomaterials 2010;31:8121-31.

[27] Debelle L, Alix AJP, Wei SM, Jacob MP, Huvenne JP, Berjot M, et al. The secondary structure and architecture of human elastin. Eur J Biochem 1998;258:533-9.

[28] Bonnier F, Rubin S, Debelle L, Venteo L, Pluot M, Baehrel B, et al. FT-IR protein secondary structure analysis of human ascending aortic tissues. J Biophoton 2008;1:204-14.

[29] Dyksterhuis LB, Carter EA, Mithieux SM, Weiss A. Tropoelastin as a thermodynamically unfolded premolten globule protein: the effect of trimethylamine $N$ oxide on structure and coacervation. Arch Biochem Biophys 2009;487:79-84.

[30] Salvi AM, Moscarelli P, Satriano G, Bochicchio B, Castle JE. Influence of amino acid specificities on the molecular and supramolecular organization of glycine-rich elastin-like polypeptides in water. Biopolymers 2011;95:702-21.

[31] Tamburro AM, Panariello S, Santopietro V, Bracalello A, Bochicchio B, Pepe A Molecular and supramolecular structural studies on significant repetitive sequences of resilin. Chem Bio Chem 2010;11:83-93.

[32] Lopes DHJ, Meistert A, Gohlke A, Hauser A, Blume A, Winter R. Mechanism of islet amyloid polypeptide fibrillatin at lipid interfaces studied by infrared reflection absorption spectroscopy. Biophys J 2007;93:3132-41.

[33] Samouillan V, Dandurand-Lods J, Lamure A, Maurel E, Lacabanne C, Gerosa G, et al. Thermal analysis characterization of aortic tissues for cardiac valves bioprostheses. J Biomed Mat Res 1999;46:531-8.

[34] Sionkowska A, Skopinska-Wisniewska J, Gawron M, Kozlowska J, Planecka A. Chemical and thermal cross-linking of collagen and elastin hydrolysates. Int J Biol Macromol 2010;47:570-7. 
[35] Puett D. DTA and heats of hydration of some polypeptides. Biopolymers 1967;5:327-30.

[36] Megret C, Lamure A, pieraggi MT, Lacabanne C, Guantieri V, tamburro AM. Solid-state studies on synthetic fragments and analogues of elastin. Int J Biol Macromol 1993;15:305-12.

[37] Hoeve CAJ, Flory CAJPJ. The elastic properties of elastin. Biopolymers 1974;13: 677-86.

[38] Samouillan V, Dandurand J, Lacabanne C, Hornebeck W. Molecular mobility of elastin: effect of molecular architecture. Biomacromolecules 2002;3:531-7.

[39] McCrystal CB, Ford JL, Rajabi-Siahboomi AR. Water distribution Studies within cellulose ethers using differential scanning calorimetry 1 . Effect of polymer molecular weight and drug addition. J Pharm Sci 1999;88:792-6.

[40] Hatakeyama H, Hatakeyama T. Interaction between water and hydrophilic polymers. Thermochim Acta 1998;308:3-22.

[41] Dzwolak W, Ravindra R, Winter R. Hydration and structure: the two sides of the insulin aggregation process. Phys Chem Chem Phys 2004:6:1938-43.

[42] Stirpe A, Rizzuti B, Pantusa M, Bartucci R, Sportelli L, Guzzi R. Thermally induced denaturation and aggregation of BLG-A: effect of the $\mathrm{Cu}^{2+}$ and $\mathrm{Zn}^{2+}$ metal ions. Eur Biophys J 2008;37:1351-60.
[43] Sasahara K, Yagi H, Naiki H, Goto Y. Heat-induced conversion of beta 2microglobulin and hen egg-white lysozyme into amyloid fibrils. J Mol Bio 2007;372:981-91.

[44] Cooper A. Heat capacity of hydrogen-bonded networks: an alternative view of protein folding thermodynamics. Biophys Chem 2000;85:25-39.

[45] Kinoshita M, Yoshidome T]. Molecular origin of the negative heat capacity of hydrophilic hydration. J Chem Phys 2009;130. 144705-1/11.

[46] Miles CA, Ghelashvili M. Polymer-in-a-box mechanism for the thermal stabilization of collagen molecules in fibres. Biophys J 1999;76:3243-52.

[47] Kaasgaard T, Mouritsen OG, Jørgensen K. Freeze/thaw effects on lipid-bilayer vesicles investigated by differential scanning calorimetry. Biochim Biophys Acta 2003;1615:77-83.

[48] Lee KY, Ha WS. DSC Studies on bound water in silk fibroin/S-carboxymethyl keratine blend films. Polymer 1999;40:4131-4.

[49] Panagopoulou A, Kyritsis A, Sabater I, Serra R, Gomez Ribelles JL, Shinyashiki N, et al. Glass transition and dynamics in BSA-water mixtures over wide ranges of composition studied by thermal and dielectric techniques. Biochim Biophys Acta 2011;1814:1984-96. 